\title{
Kernos
}

Revue internationale et pluridisciplinaire de religion grecque antique

$7 \mid 1994$

Varia

\section{J. POUCET, J.-M. HANNICK, Aux sources de l'antiquité gréco-romaine. Guide bibliographique}

\section{Vinciane Pirenne-Delforge}

\section{OpenEdition \\ Journals}

\section{Édition électronique}

URL : http://journals.openedition.org/kernos/1142

DOI : 10.4000/kernos. 1142

ISSN : 2034-7871

\section{Éditeur}

Centre international d'étude de la religion grecque antique

\section{Édition imprimée}

Date de publication : 1 janvier 1994

ISSN : 0776-3824

\section{Référence électronique}

Vinciane Pirenne-Delforge, « J. POUCET, J.-M. HANNICK, Aux sources de l'antiquité gréco-romaine. Guide bibliographique », Kernos [En ligne], 7 | 1994, mis en ligne le 20 avril 2011, consulté le 24 septembre 2020. URL : http://journals.openedition.org/kernos/1142; DOI : https://doi.org/10.4000/kernos. 1142 
et l'Atlantide. C'est leur démarche qui est envisagée dans le présent ouvrage.

Avant d'être mise en relation avec l'archipel, chacune de ces légendes est soigneusement retracée à l'aide des sources les plus explicites et les plus chargées de sens, située dans son contexte et dans son évolution, interprétée selon les grilles les mieux établies. Les exposés sont clairs, fondés sur une bibliographie, limitée mais récente, parsemés de tableaux récapitulatifs, qui reflètent de façon fort heureuse les chemins sinueux des traditions légendaires. Il ne faut donc pas s'attendre à des analyses qui renouvellent la connaissance de mythes et de fictions célèbres; ce n'est d'ailleurs pas le but de l'A. En revanche, l'excellent ouvrage de Marcos Martínez met en évidence et explique la place exceptionnelle que l'archipel des Canaries a occupée et occupe encore dans l'imaginaire occidental. À ce titre, il relève non seulement de l'étude des mythes et des Canaries, mais aussi de l'histoire des mentalités.

Monique Mund-Dopchie (Université de Louvain-la-Neuve)

J. Poucet, J.-M. Hannick, Aux sources de l'antiquité gréco-romaine. Guide bibliographique, Louvain-la-Neuve, Artel, $1993^{3} .1$ vol. $16 \times 23$ cm, 291 p. ISBN : 2-87374-019-1.

Voilà un outil de travail qui rendra de multiples services à tous ceux, étudiants, professeurs, ou amateurs éclairés, qu'intéresse la période gréco-romaine. Dans un méritoire souci de décloisonnement, c'est l'ensemble des disciplines à mettre en cuvre pour étudier l'antiquité qui sont ici envisagées. L'ouvrage s'organise en trois parties. La première présente les sources littéraires, épigraphiques, papyrologiques, archéologiques, numismatiques; la deuxième présente les grands ouvrages de consultation (dictionnaires, encyclopédies, manuels, etc.), et la troisième, sans doute la plus difficile à organiser et la plus susceptible de prêter le flanc à la critique, propose une bibliographie d'orientation couvrant à la fois l'histoire des études classiques, la transmission des textes, la littérature, la linguistique, l'histoire générale, la vie sociale, économique, la religion et la mythologie, la pensée morale, sociale, politique, philosophique, les arts, la survie et les héritages de l'antiquité. Des index complètent l'ouvrage et en facilitent la consultation.

Vinciane Pirenne-Delforge (Université de Liège) 